\title{
Pulmonary adenocarcinoma in a captive ocelot (Leopardus pardalis): morphologic and immunophenotypic characterization - case report
}

\author{
[Adenocarcinoma pulmonar em uma jaguatirica (Leopardus pardalis) de cativeiro: \\ caracterização morfológica e imunofenotípica - relato de caso] \\ A.R. Oliveira ${ }^{1}$, F.M.A.M. Pereira ${ }^{2}$ (D) D.O. Santos $^{1}{ }^{\mathbb{D}}$, T.P. Carvalho $^{1}(\mathbb{D}$, \\ L.L. Soares-Neto ${ }^{2}$, R.L. Santos ${ }^{1 *}$ \\ ${ }^{1}$ Universidade Federal de Minas Gerais, Escola de Veterinária, Belo Horizonte, MG, Brasil \\ ${ }^{2}$ Parque Zoológico Municipal de Bauru, Setor de Veterinária, Bauru, SP, Brasil
}

\begin{abstract}
Pulmonary adenocarcinoma is a malignant epithelial neoplasia that usually arises from conducting airways or alveolar parenchyma. It has rarely been described in wild felids, with no previous reports in ocelots. In domestic cats it is a very aggressive neoplasm with a high metastatic rate that usually evolves to death. This report aimed to describe a pulmonary adenocarcinoma in a captive and senile ocelot (Leopardus pardalis), with a thorough morphologic and immunophenotypically characterization, evidencing the epithelial-mesenchymal transition (EMT) phenomenon in a high metastatic carcinoma, an important feature rarely described in veterinary medicine, even in domestic cats.
\end{abstract}

Keywords: pathology, oncology, EMT, wild felid, immunohistochemistry

\section{RESUMO}

O adenocarcinoma pulmonar é uma neoplasia epitelial maligna originada do epitélio respiratório das vias aéreas inferiores e do parênquima alveolar. É uma neoplasia raramente descrita em felinos selvagens, sem nenhum relato em jaguatiricas. Em gatos domésticos, é uma neoplasia muito agressiva, com alta taxa de metástase, e geralmente evolui para o óbito do paciente. O presente relato objetiva descrever um adenocarcinoma pulmonar em uma jaguatirica (Leopardus pardalis) senil de cativeiro, com detalhada caracterização morfológica e imunofenotípica, evidenciando o fenômeno de transição epitelial-mesenquial (TEM) em um carcinoma altamente metastático, uma característica importante, com escassos relatos na medicina veterinária, mesmo em gatos domésticos.

Palavras-chave: patologia, oncologia, TEM, felino selvagem, imuno-histoquímica

\section{INTRODUCTION}

Neoplasia in wild captive felids has been increasingly reported in the past few years, mostly associated with a longer life span in captivity, genetic and environmental factors, and oncogenic infectious agent, particularly the feline leukemia virus (FeLV) and the feline immunodeficiency virus (FIV) (Owston et al., 2008; Junginger et al., 2015; Kloft et al., 2019). In captive felids, neoplasia could represent more than $20 \%$ of the causes of death, with mean age of 15 to 16 years old (Owston et al., 2008; Junginger et al., 2015). There are only a few reports of primary lung neoplasia in wild felids (Junginger et al., 2015; Kloft et al., 2019), none of these previously reported cases affected a neotropical felid species. This report aims to describe a case of pulmonary adenocarcinoma in a captive ocelot (Leopardus pardalis) with a detailed morphologic and immunophenotypic assessment of the neoplasm.

*Corresponding author: rsantos@ vet.ufmg.br

Submitted: February 4, 2021. Accepted: June 15, 2021. 


\section{CASE REPORT}

A captive 15-year-old male ocelot (Leopardus pardalis) born and housed at the Bauru Zoological Garden (Bauru, Brazil), presented with anorexia for three days. Three days later, the animal became dyspneic so at the fourth day the animal was chemically restrained with ketamine $\quad(5 \mathrm{mg} / \mathrm{kg}, \quad \mathrm{IM})$, dexmedetomidine $(0.012 \mathrm{mg} / \mathrm{kg}, \mathrm{IM})$ and midazolam $(0.1 \mathrm{mg} / \mathrm{kg}$,
IM) for a thorough clinical evaluation. However, during the anesthetic procedure the animal had a cardiorespiratory arrest and died. Chest radiographs were taken immediately after death, and the animal was sent to necropsy. Chest radiographs revealed a pleural effusion with an evident radiopaque nodule in the lung topography and an interstitial pulmonary pattern (Fig. 1)
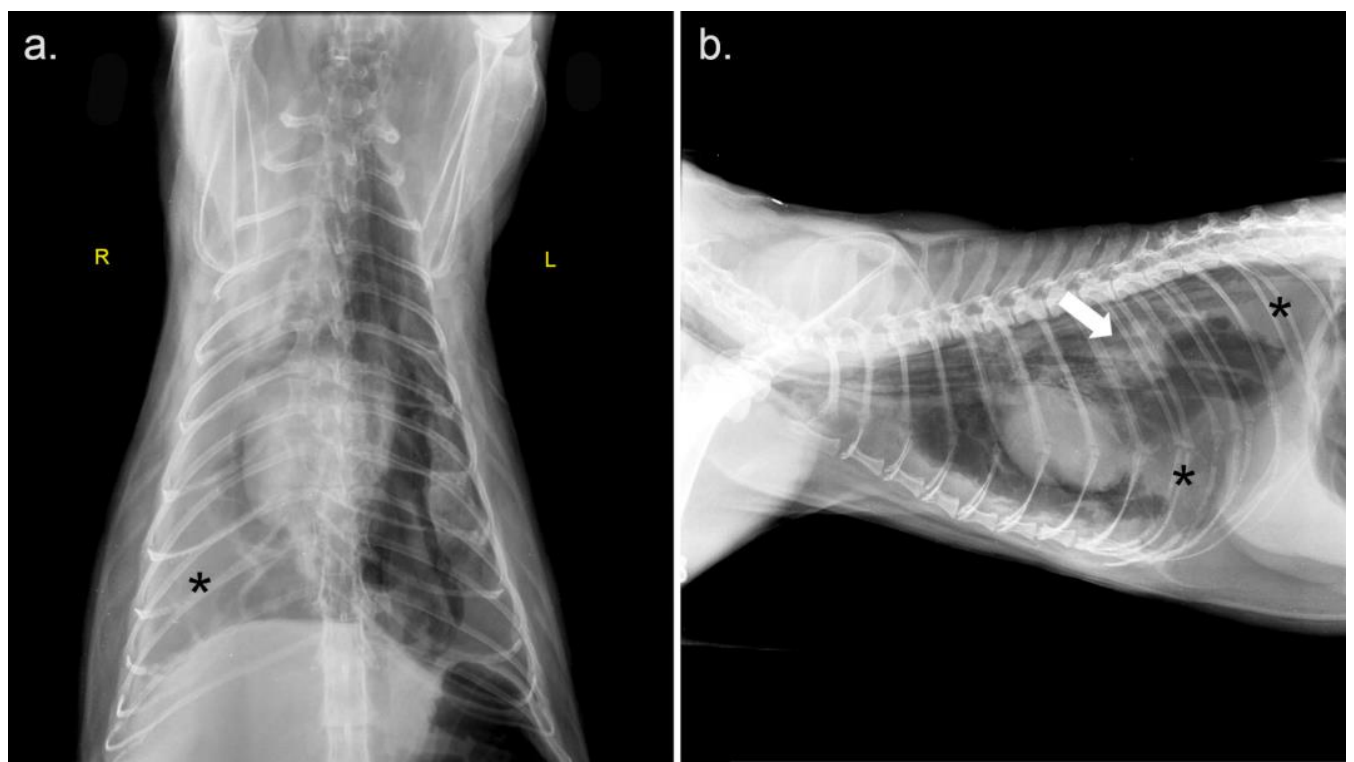

Figure 1. Radiographs of a captive ocelot (Leopardus pardalis) with pulmonary adenocarcinoma. (a) Ventral-dorsal image of the thorax evidencing the pleural effusion $\left(^{*}\right)$. (b) Latero-lateral image of the thorax with a visible radiopaque nodule at lung topography (white arrow) and pleural effusion $(*)$.

Grossly, there were 1.3 liters of free bloody exudate in the thoracic cavity. The exudate was turbid, reddish, and rich in erythrocytes, inflammatory cells, and reactive mesothelial cells. Multiple, white, firm, and small nodules $(<0.5 \mathrm{~cm}$ in diameter) were observed diffusely distributed within the thoracic cavity, attached to the mediastinal and visceral pleura (Fig. 2a). The lung was diffusely firm, hypocrepitant, greyish red, with multiple whitish and small $(<1.0 \mathrm{~cm}$ in diameter) nodules (Fig. 2b). Samples of the lungs, pleural nodules, mediastinal lymph nodes, heart, spleen, pancreas, intestine, stomach, liver, urinary bladder, and kidney were collected, fixed in $10 \%$ buffered formalin, processed for paraffin embedding, sectioned in a microtome $(4 \mu \mathrm{m}$-thick sections), and stained with eosin and hematoxylin (HE).
Microscopically, pulmonary neoplastic nodules were characterized by multifocal to coalescent areas of replacement of the normal pulmonary parenchyma with an expansive non-encapsulated epithelial neoplasia, arranged predominantly in a papillary pattern forming projections of epithelial cells, predominantly in monolayer, supported by fibrovascular connective tissue (Fig. 2c). Neoplastic cells were cuboidal to columnar with a large and eosinophilic cytoplasm and a high nucleus:cytoplasm ratio. Nuclei were large, predominantly rounded, sometimes oval to elongated, with loose chromatin and prominent single to multiple nucleoli. There were 20 mitotic figures per ten high power microscopic fields, with moderate anisocytosis and anisokaryosis, and marked nuclear pleomorphism. The lumen of the structures formed by neoplastic cells was filled with an amorphous eosinophilic material and detached neoplastic cells, 
neutrophils, and foamy macrophages. The pulmonary parenchyma adjacent to the neoplasm had severe atelectasis. There were some areas of necrosis at the center of the neoplasm, sometimes with neutrophils and cholesterol clefts.

In other sections of the lung parenchyma, representative of the firm and greyish areas observed grossly, neoplastic cells had a more infiltrative aspect, involving extensive areas of the lung, organized predominantly in a papillary pattern and a few areas of a micropapillary pattern, with several neoplastic cells detached from the basement membrane. In some fields, there were neoplastic cells arising from the bronchiolar epithelium (Fig. 2d). In these areas, 15 mitotic figures were observed in ten high power microscopic fields, with slight dyskeratosis and foci of squamous metaplasia. Moderate multifocal perivascular lymphoplasmacytic infiltrate was observed. There were occasional emboli composed of neoplastic cells, eventually with vascular recanalization. Nodules observed on the pleura had the same morphological aspect of the neoplasm in the lung. Metastatic foci were also observed in the spleen and mediastinal lymph nodes.
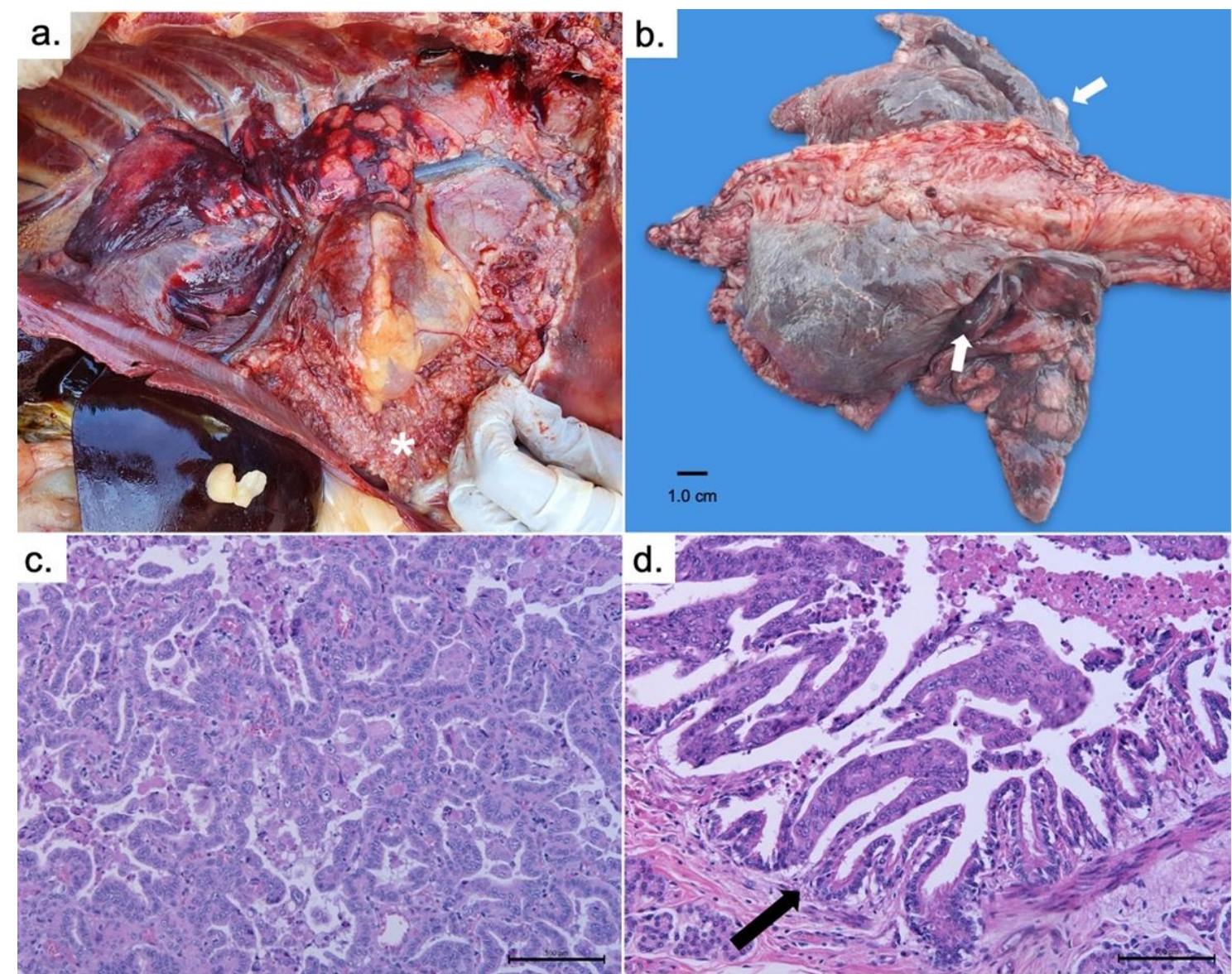

Figure 2. Gross and histopathologic findings of a captive ocelot (Leopardus pardalis) with pulmonary adenocarcinoma. (a) Thoracic cavity with multiple and millimetric nodules on the mediastinal pleura (*) compatible with carcinomatosis. (b) Lung with multiple and well delimited white nodules (white arrow) and a diffuse firm and grayish appearance. (c) Epithelial and papillary neoplasia, lung, HE, 200x. (d) Neoplastic cells arising from bronchiolar epithelium (black arrow), lung, HE, 200x.

A immunohistochemistry panel was performed. Primary antibodies, sources, dilutions, and antigen retrieval systems are detailed in Table 1. The Envision Dual Link (DAKO, USA) was used as detection system for all primary antibodies, and diaminobenzidine (DAB) was used as chomogen (DAKO, USA). Neoplastic cells in the lung and metastatic sites were 
consistently positive for pan-cytokeratin, CK7, CK20, TTF-1, and Napsin A (Fig. 3a-d). Neoplastic cells were negative for thyroglobulin, CDX2, calretinin, and WT-1. In addition, pulmonary neoplastic tissues as well as neoplastic cells in lymph nodes and splenic metastasis were predominantly vimentin negative (Fig. 3e). However, neoplastic cells detached from basal membrane in the lung neoplasia and neoplastic cells in the pleura were often vimentin positive (Fig. 3e-f). Morphology and immunohistochemical profile were compatible with a metastatic pulmonary adenocarcinoma with thoracic carcinomatosis.

\section{DISCUSSION}

Pulmonary adenocarcinoma is a malignant epithelial neoplasm that usually arises from conducting airways or alveolar parenchyma. In domestic cats it is considered a very aggressive neoplasm that usually evolves to metastasis, especially in intra-thoracic sites, and it is often observed in senile cats (Wilson, 2017), which is in accordance with this case. Pulmonary tumors have been well characterized in domestic cats based on their pathologic features (Barr et al., 1987; Zanoni et al., 2017) as well as on various diagnostic imaging techniques (Miles, 1988; Nunley et al., 2015). It is classified as lepidic (butterfly-like pattern), papillary, micropapillary, acinar, solid predominant with mucin production, and squamous, according to its predominant morphologic pattern, with micropapillary pattern being the most aggressive type (Wilson, 2017; Romanucci et al., 2018). The ocelot in this case had a predominantly papillary adenocarcinoma with multiple sites of micropapillary pattern.

Interestingly, two distinct morphologic patterns were observed in this case based on gross and histopathologic features: there was a nodular and expansive proliferative pattern, visible on the radiographs, with papillary pattern and more well-differentiated cells and another diffuse and infiltrative proliferation with more pleomorphic cells, which was diffuse, with no grossly recognizable nodules. These morphologic features have been rarely observed in domestic animals, but it has been once reported in a domestic cat with micropapillary pattern (Romanucci et al., 2018).

Another important feature of the neoplasm in this case was the marked vimentin expression by detached neoplastic cells at the primary tumor site as well as in areas of carcinomatosis. This atypical vimentin expression in epithelial neoplasms could be explained by the phenomenon called epithelial-mesenchymal transition (EMT), more studied in human neoplasms, which in some carcinomas correlates with higher metastatic rates and lower survival rates (Hugo et al., 2007). EMT occurs when the neoplastic cell loses its polarity and cohesion with basal membrane and starts tissue invasion, acquiring a mesenchymal phenotype and in some stages keeping cytokeratin expression (Hugo et al., 2007) as observed in this case. In domestic cats there are some previous reports that demonstrated this feature in carcinomas (de las Mulas et al., 1994; Sarli et al., 2006; Volmer et al., 2009; Harris et al., 2019).

Table 1. Antibodies panel used to characterize the lung tumor and metastasis from the ocelot (Leopardus pardalis)

\begin{tabular}{|c|c|c|c|c|c|}
\hline Antibody & Clone & Manufacturer & Dilution & $\begin{array}{l}\text { Antigen } \\
\text { retrieval* }\end{array}$ & Immunolabeling results \\
\hline Pan-cytokeratin & AE1AE3 & $\begin{array}{l}\text { Santa Cruz } \\
\text { Biothecnology }\end{array}$ & $1: 100$ & HIER, $\uparrow p H$ & Positive in all neoplastic cells \\
\hline CK20 & Ks 20.8 & Zeta & $1: 50$ & Pepsin & Positive in all neoplastic cells \\
\hline TTF-1 & $8 \mathrm{G} 7 \mathrm{G} 3 / 1$ & Spring Bioscience & $1: 100$ & HIER, $\downarrow \mathrm{pH}$ & Positive in all neoplastic cells \\
\hline Napsin A & $\mathrm{BC} 15$ & Biocare Medical & $1: 100$ & HIER, $\uparrow \mathrm{pH}$ & Positive in all neoplastic cells \\
\hline $\mathrm{CDX} 2$ & DAK-CDX2 & Dako & ready & HIER, $\uparrow \mathrm{pH}$ & Negative in all neoplastic cells \\
\hline WT-1 & $6 \mathrm{~F}-\mathrm{H} 2$ & Dako & ready & HIER, $\uparrow \mathrm{pH}$ & Negative in all neoplastic cells \\
\hline \multirow[t]{2}{*}{ Calretinin } & polyclonal & Spring Bioscience & $1: 200$ & HIER, $\downarrow \mathrm{pH}$ & Negative in all neoplastic cells \\
\hline & & Santa Cruz & $1: 100$ & HIER, $\uparrow \mathrm{pH}$ & Positive in detached neoplastic \\
\hline Vimentin & RV202 & Biothecnology & & & $\begin{array}{l}\text { cells in the lung and in areas of } \\
\text { carcinomatosis }\end{array}$ \\
\hline
\end{tabular}

* HIER: heat induced epitope retrieval; $\uparrow \mathrm{pH}$ : high $\mathrm{pH}(50 \mathrm{x}$ Tris/EDTA buffer, $\mathrm{pH} 9$ ); $\downarrow \mathrm{pH}$ : low pH (50x citrate). 

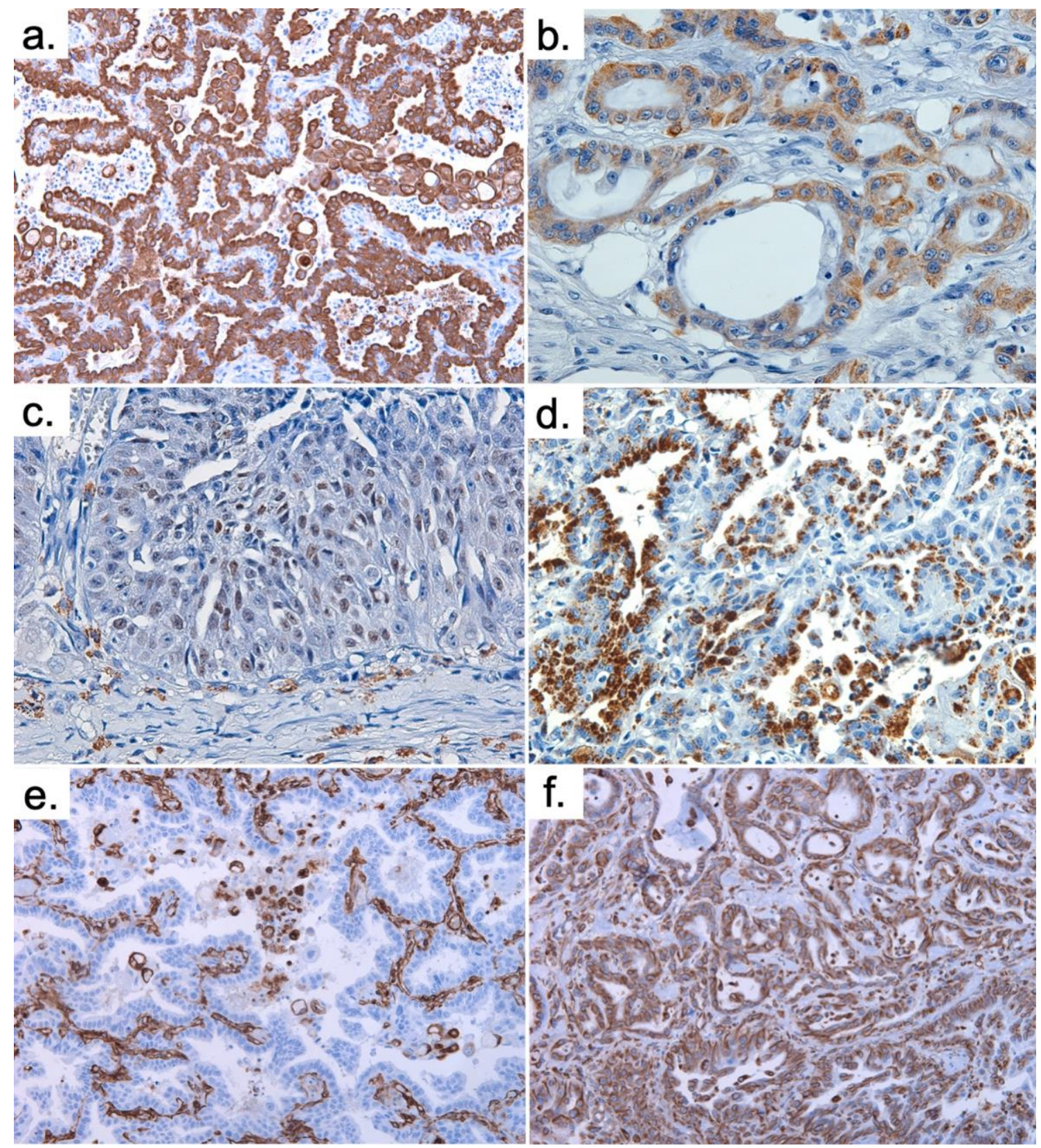

Figure 3. Immunohistochemistry of the lung from the captive ocelot (Leopardus pardalis) with pulmonary adenocarcinoma. Immunolabeling revealed with DAB of pan-cytokeratin, 200x (a), CK7, 400x (b), TTF-1, 400x (c), Napsin A, 400x (d) and vimentin, from primary neoplasia, 200x (e) and pleural carcinomatosis, 200x (f).

Concurrent vimentin and cytokeratin expression are also observed in mesotheliomas, a neoplasia that could have the same gross appearance of our case with similar histopathologic features. There are some reports of mesotheliomas in wild felids (Bollo et al., 2011; Junginger et al., 2015) being an important differential diagnosis in this case. However, none of the neoplastic cells (from primary tumor or metastasis) expressed calretinin and WT-1, two markers that are usually observed in mesothelial cells (Wilson, 2017; Marcos et al., 2019). Importantly, both markers were expressed by internal control of mesothelial cells. Additionally, histopathologic evaluation revealed the proliferation of neoplastic cells arising from bronchiolar epithelium, compatible with the 
diagnosis of pulmonary adenocarcinoma. Neoplastic cells were consistently positive to TTF-1 and Napsin A, two markers expressed in lung carcinomas (Wilson, 2017). Finally, to rule out the possibility of a carcinoma of thyroid or intestinal origin, expression of thyroglobulin and CDX2 was assessed, respectively, both yielding negative in all neoplastic cells.

The ocelot (Leopardus pardalis) is a wild neotropical felid with occurrence from Mexico to Brazil and, like all neotropical felids, is having an important decrease of its free-ranging population (Paviolo et al., 2015), which makes captive animals extremally important for ex situ conservational programs.

\section{CONCLUSION}

This is the first report of a pulmonary adenocarcinoma in an ocelot, with a distinct gross and histopathologic feature and a detailed immunophenotypically characterization, evidencing the EMT phenomenon in a high metastatic carcinoma, an important, rarely described feature, even in domestic cats.

\section{ACKNOWLEDGEMENTS}

Work in RLS lab is supported by $\mathrm{CNPq}$ (Conselho Nacional de Desenvolvimento Científico e Tecnológico, Brazil), FAPEMIG (Fundação de Amparo a Pesquisa do Estado de Minas Gerais, Brazil), and CAPES (Coordenação de Aperfeiçoamento de Pessoal de Nível Superior, Brazil). RLS has a fellowship from CNPq (Brazil).

\section{REFERENCES}

BARR, F.; GRUFFYDD-JONES, T.J.; BROWN, P.J. et al. Primary lung tumours in the cat. J. Small Anim. Pract., v.28, p.1115-1125, 1987.

BOLLO, E.; SCAGLIONE, F.E.; TURSI, M. et al. Malignant pleural mesothelioma in a female Lion (Panthera leo). Res. Vet. Sci., v.91, p.116-118, 2011.

DE LAS MULAS, J.M.; DE LOS MONTEROS, A.E.; BAUTISTA, M.J. et al. Immunohistochemical distribution pattern of intermediate filament proteins and muscle actin in feline and human mammary carcinomas. J. Comp. Pathol., v.111, p.365-381, 1994.

HARRIS, K.; GELBERG, H.B.; KIUPEL, M.; HELFAND, S.C. Immunohistochemical features of epithelial-mesenchymal transition in feline oral squamous cell carcinoma. Vet. Pathol., v.56, p.826839, 2019.
HUGO, H.; ACKLAND, M.L.; BLICK, T. et al. Epithelial-mesenchymal and mesenchymal-epithelial transitions in carcinoma progression. J. Cell. Physiol., v.213, p.374-383, 2007.

JUNGINGER, J.; HANSMANN, F.; HERDER, V. et al. Pathology in captive wild felids at German zoological gardens. Plos One, v.10, e0130573, 2015.

KLOFT, H.M.; RAMSAY, E.C.; SULA, M.M. Neoplasia in captive Panthera species. J. Comp. Pathol., v.166, p.35-44, 2019.

MARCOS, R.; MARRINHAS, C.; MALHÃO, F. et al. The cell tube block technique and an immunohistochemistry panel including Wilms tumor 1 to assist in diagnosing cavitary effusions in dogs and cats. Vet. Clin. Pathol., v.48, p.1-11, 2019.

MILES, K.G. A review of primary lung tumors in the dog and cat. Vet. Radiol., v.29, p.122-128, 1988.

NUNLEY, J.; SUTTON, J.; CULP, W. et al. Primary pulmonary neoplasia in cats: assessment of computed tomography findings and survival. J. Small Anim. Pract., v.56, p.651-656, 2015.

OWSTON, M.A.; RAMSAY, E.C.; ROTSTEIN, D.S. Neoplasia in felids at the Knoxville Zoological Gardens, 1979-2003. J. Zoo Wildl. Med., v.39, p.608613,2008

PAVIOLO, A.; CRAWSHAW, P.; CASO, A. et al. Leopardus pardalis (errata version published in 2016). IUCN Red list of threatened species. 2015. Available in: $\quad$ http://dx.doi.org/10.2305/IUCN.UK.20154.RLTS.T11509A50653476.en. Accessed in: 26 May, 2021.

ROMANUCCI, M.; MASSIMINI, M.; ASTE, G. et al. Diffuse pulmonary adenocarcinoma with micropapillary growth pattern in a cat. J. Comp. Pathol., v.160, p.34-38, 2018.

SARLI, G.; BRUNETTI, B.; BENAZZI, C. Mammary mucinous carcinoma in the cat. Vet. Pathol., v.43, p.667-673, 2006.

VOLMER, C.; BENALI, Y.; CAPLIER, L. et al. Atypical vimentin expression in a feline salivary gland adenocarcinoma with widespread metastases. J. Vet. Med. Sci., v.71, p.1681-1684, 2009.

WILSON, D.W. Tumors of the respiratory tract. In: MEUTEN, D.J. (Ed.). Tumors in domestic animals. 5.ed. Iowa: Wiley Blackwell, 2017. p.467-498.

ZANONI, D.S.; RIVERA-CALDERON, L.G.; SILVA, G.A. et al. Immunohistochemistry characterization of a bronchioloalveolar carcinoma mixed subtype in cat. Braz. J. Vet. Pathol., v.10, p.3237, 2017. 